JUPIIS: Jurnal Pendidikan Ilmu-ilmu Sosial, 12(1) (2020): 220-229

DOI: https://doi.org/10.24114/jupiis.v12i1.16031

JUPIIS: Jurnal Pendidikan Ilmu-Ilmu Sosial

Available online http://jurnal.unimed.ac.id/2012/index.php/jupiis

\title{
Adaptasi Berbasis Budaya dan Sosial Masyarakat (Studi Kasus Etnis Tionghoa di Kota Palembang)
}

\author{
Cultural and Social Based Adaptation \\ (Case Study of Chinese Ethics in Palembang City) \\ Nursapia Harahap \\ Program Studi Ilmu Komunikasi, Fakultas Ilmu Sosial, Universitas Islam Negeri \\ Sumatera Utara \\ Diterima: 19 Desember 2019; Disetujui: 22 Maret 2020; Diterbitkan: 30 April 2020.
}

\begin{abstract}
Abstrak
Adaptasi bergantung pada struktur atau perilaku fisik individu yang meningkatkan kemampuannya untuk bertahan hidup di habitatnya. Apa pun yang membantunya bertahan hidup di lingkungan yang ditempatinya termasuk budaya dan social masyarakat. Mengingat adapatasi mengacu pada kemampuan untuk menyesuaikan diri dengan berbagai kondisi dalam lingkungannya. Penelitian ini bertujuan untuk menganalisis adapatasi budaya dan adaptasi social masyarakat etnis Tionghoa dalam teori dan praktek. Kemudian memperjelas peran penting yang dimainkan budaya dalam memampukan adaptasi, dan menunjukkan bagaimana adaptasi berbasis budaya dan sosial masyarakat ditempatkan dengan baik. Disamping itu juga mengukur titik tolak khas pembangunan masyarakat yang baik dengan menekankan partisipasi masyarakat, sistem kekerabatan, kesejahteraan individu, budaya, komunitas dan adaptasi. Untuk itu secara khusus dalam penelitian ini mengandalkan pemikiran yang telah muncul dari pengamatan tentang peran budaya dan sosial masyarakat dalam kehidupan individu. Hasil penelitian ini menunjukkan bahwa Etnis Tionghoa sudah mampu melakukan adaptasi budaya dan sosial masyarakat dengan baik di Kota Palembang. Kemampuan tersebut terlihat dari kehidupan sosial ekonomi, kemasyarakatan dan budaya etnis Tionghoa yang mampu bertahan hidup dengan modal pengembangan usaha dagang dan berkecimpung di bidang politis. Selain itu, etnis Tionghoa juga mampu beradaptasi secara struktural dan kultural dengan mengikuti perkembangan budaya dan masyarakat Kota Palembang.
\end{abstract}

Kata Kunci: Adaptasi, Budaya, Sosial, Masyarakat

\begin{abstract}
Adaptation depends on the structure or physical behavior of an individual that increases his ability to survive in his habitat. Whatever helps him survive in the environment he occupies includes the cultural and social community. Remembering adaptation refers to the ability to adapt to various conditions in their environment. This study aims to analyze the cultural adaptation and social adaptation of ethnic Chinese communities in theory and practice. Then clarify the important role that culture plays in enabling adaptation, and show how community-based cultural and social adaptation is well placed. Besides that it also measures the typical starting point of good community development by emphasizing community participation, kinship systems, individual welfare, culture, community and adaptation. For this reason, in particular this research relies on thoughts that have emerged from observations about the cultural and social role of society in individual lives. The results of this study indicate that the Chinese ethnic has been able to adapt to the cultural and social adaptation of the community well in the city of Palembang. This ability can be seen from the socio-economic life, society and culture of ethnic Chinese who are able to survive with the capital of developing business ventures and working in the political field. In addition, the Chinese are also able to adapt structurally and culturally by following the cultural and community development of Palembang City.

Keywords: Adaptation, Culture, Social, Community
\end{abstract}

How to Cite: Harahap, N. (2020). Adaptasi Berbasis Budaya dan Sosial Masyarakat. JUPIIS: Jurnal Pendidikan Ilmu-ilmu Sosial. 12(1): 220-229

${ }^{*}$ Corresponding author:

E-mail: harahap.nursapia@gmail.com 


\section{PENDAHULUAN}

Pemahaman terhadap budaya memainkan peranan yang sangat penting didalam dalam proses adaptasi (Stavenhagen, 1998) mengemukakan tiga definisi budaya: sebagai modal, sebagai kreativitas, atau sebagai cara hidup total. Di sini, pandangan ketiga tersebut diasumsikan dalam referensi budaya, artinya jumlah total dari aktivitas material, spiritual dan produk dari kelompok sosial tertentu. Dengan kata lain, nilai dan simbol serta serangkaian praktik yang direproduksi oleh kelompok tertentu dari waktu ke waktu dan memberikan individu rambu-rambu dan makna untuk berperilaku.

Namun, kebutuhan untuk beradaptasi dengan perubahan iklim budaya dapat menekan individu dan mempengaruhi mata pencaharian, gaya hidup atau pola perilaku yang berpotensi menantang gagasan budaya yang ada. Serangkaian pertanyaan muncul: apakah, dan jika demikian bagaimana caranya, budaya bersama menyediakan, mengubah atau membatasi opsi untuk adaptasi? Bagaimana dan mengapa individu dalam komunitas merespons prospek perubahan dalam kehidupan dan mata pencaharian mereka? dan yang terpenting, pelajaran apa yang muncul mereka yang bekerja untuk mengamankan kehidupan dan mata pencaharian dalam menghadapi perubahan iklim budaya?

Definisi budaya Stavenhagen menunjukkan saling ketergantungan yang penting antara kelompok dan individu. Prospek otonomi individu dibatasi oleh lingkungan budaya yang dipegang secara komunal telah lama menjadi istimewa menarik bagi para filsuf politik, karena merupakan fokus dari ketidaksepakatan antara sekolah liberal dan komunitarian. Will Kymlicka dan Joseph Raz secara khusus berusaha untuk memperjelas sifat hubungan antara individu dan komunitas budaya mereka. Raz dan Kymlicka bukanlah satu-satunya filsuf yang ahli dalam masalah ini, sebagai pusat bagi sekolah komunitarian. Lihat, misalnya, karya Van Dyke sebelumnya tentang kaum liberal pendekatan terhadap hakhak kelompok (Van Dyke, 1977), atau, sebelumnya, kritik Hegel terhadap liberalisme dan saling ketergantungan individu dan masyarakat (Kymlicka, 2002). Pekerjaan mereka menawarkan wawasan berharga bagi mereka yang mencoba memahami peran budaya dalam kehidupan individu dan bagaimana kaitannya dengan tantangan adaptasi.

Adaptasi berbasis budaya dan masyarakat secara implisit meyakini bahwa referensi eksplisit untuk peran budaya diperlukan untuk memastikan bahwa kekuatan yang melekat dari adaptasi berbasis komunitas dapat dilaksanakan dalam praktek hubungan sosial individu dengan individu atau kelompok lainnya. Adaptasi berbasis komunitas telah didefinisikan sebagai suatu proses yang berfokus pada komunitas-komunitas yang paling rentan terhadap perubahan iklim budaya. Apalagi dengan multikulturalisme yang sangat beragam.

Indonesia telah menjadi negara yang multietnik sejak masa kolonial, dengan membagi stratifikasi sosial dalam tiga golongan, yaitu; ras kulit putih (Belanda) dengan status kelas sosial yang paling tinggi, ras timur asing atau kulit kuning (Arab, Cina, India) sebagai kelas sosial kedua, dan ras pribumi sebagai 
kelas sosial yang paling rendah. Geertz dalam Anshory (2008) bahwa Indonesia begitu kompleks sehingga sulit memaparkan keseluruhan Indonesia secara persis, karena Indonesia bukan hanya multietnis (Jawa, Batak, Bugis, Flores, Bali dan sebagainya) melainkan juga dipengaruhi oleh budaya multimental yang dibawa negara lain (India, Cina, Belanda, Portugis, Hinduisme, Budhaisme, Konfisianisme, Islam, Kristen, Kapitalis, dsb.).

Indonesia terdiri dari sejumlah ras dengan jumlah, makna, dan karakter yang berbeda-beda yang memiliki sejarah, ideologi, agama, tersusun sebagai sebuah struktur ekonomi dan politik bersama. Beberapa keanekaragaman Indonesia dalam kondisi kompleksitas ini tentu memiliki nilai-nilai yang baik yang tetap hidup dan dianut hingga saat ini.

Nilai-nilai ini mengandung pedoman hidup, norma-norma, etika, dan estetika. Hal tersebut sangat berpengaruh pada kelangsungan hidup dan martabat bangsa apabila bangsa Indonesia mampu memanfaatkannya dengan baik. Kekayaan keanekaragaman budaya bangsa sebagai dasar perwujudan dari pembangunan karakter bangsa, bangsa yang bermartabat, bermoral, ramah tamah, cinta lingkungan, adil, hidup rukun dan toleransi dengan nasionalisme tinggi yang merupakan harapan dari seluruh warga negara. Salah satu kompleksnya Indonesia secara horizontal adanya keberagaman etnis. Etnisetnis di Indonesia tersebar dari wilayah Sabang hingga Merauke.

Terdapat etnis yang memang berasal dari indonesia sebagai etnis pribumi, maupun etnis yang berasal dari keturunan etnis bangsa lain yang telah menetap di Indonesia secara turun temurun dan menjadi bagian dari warga negara Indonesia, salah satunya adalah etnis Tionghoa. Etnis Tionghoa di Indonesia merupakan hasil dari keturunan bangsa Cina yang merantau ke Indonesia kemudian menetap dan memiliki keturunan, baik dengan sesama orang Cina, maupun dengan melakukan pernikahan campur dengan etnis pribumi. Dengan dasar pemahaman bagaimana perubahan budaya akan memengaruhi lingkungan lokal dan aset dan kapasitas masyarakat (Huq dan Reid, 2007).

Berakar dari konteks lokal dan mengharuskan mereka yang membaur dengan masyarakat untuk terlibat kapasitas adat, pengetahuan dan praktik sosial. Tujuannya adalah untuk memungkinkan masyarakat memahami dan mengintegrasikan konsep risiko perubahan budaya ke dalam kegiatan mata pencaharian mereka untuk meningkatkan daya tahan mereka terhadap variabilitas perubahan iklim budaya langsung dan iklim budaya jangka panjang. Fenomena ini terjadi di nusantara Indonesia khususnya di Kota Palembang. Kondisi kependudukan masyarakat Palembang pada tabel berikut ini:

Tabel.1 Komposisi Penduduk Berdasarkan Etnis dan Agama

\begin{tabular}{lll}
\hline No. & Jenis Agama & Persentase \\
\hline 1 & Islam & $91.93 \%$ \\
2 & Buddha & $3.46 \%$ \\
3 & Kristen Protestan & $2.87 \%$ \\
4 & Katolik & $1.65 \%$ \\
5 & Hindu & $0.08 \%$ \\
6 & Konghucu & $0.01 \%$ \\
\hline
\end{tabular}


Berdasarkan Sensus Penduduk tahun 2015, persentase agama penduduk Kota Palembang adalah Islam 91.93\%, Buddha 3.46\%, Kristen Protestan 2.87\%, Katolik 1.65\%, Hindu $0.08 \%$ dan Konghucu 0.01\%. Agama mayoritas di Palembang adalah Islam. Di dalam catatan sejarahnya, Palembang pernah menerapkan undang-undang tertulis berlandaskan Syariat Islam, yang bersumber dari kitab Simbur Cahaya. Selain itu terdapat pula penganut Katolik, Protestan, Hindu, Buddha dan Konghucu (BPS, 2018).

Kehidupan masyarakat pendatang di Kota Palembang terdokumentasi dalam sejarah panjang sejak tahun 1970-an. Sebagai kota yang kaya budaya, dapat digunakan untuk memahami adaptasi, pandangan dan dinamika kehidupan masyarakat pendatang di wilayah ini. Dikarenakan adaptasi merupakan produk kultural yang mengandung berbagai hal yang menyangkut hidup dan kehidupan komunitas pemiliknya, misalnya sistem nilai, kepercayaan dan agama, kaidahkaidah sosial, etos kerja, bahkan penjabaran dinamika sosial masyarakatnya. Kota Palembang terkenal dengan sebutan kota pem-pek. Sebutan itu sebagai gambaran bahwa jenis makanan ini yang paling banyak dijual disana dan menjadi ciri khas makanan Palembang.

Pempek yang merupakan ciri khas makanan asli Palembang ternyata menurut sejarah adanya pempek setelah etnis cina masuk ke kota ini. Tahun ke 1617 seorang apek berusia 65 tahun yang tinggal didaerah tepian sungai Musi merasa prihatin melihat tangkapan ikan yang berlimpah dari sungai Musi yang belum seluruhnya bisa dimanfaatkan untuk olahan lain kecuali konsumsi sehari hari.

Beliau mengolah ikan dicampur dengan tepung tapioka sehingga muncul makanan baru. Makanan baru tersebut di jajakan kesetiap kampung dengan naik sepeda. Karena penjualnya dipanggil "Pek- maka makanan itu dikenal dengan pempek. Makanan pempek menjadi makanan khas masyarakat mulai dari sarapan pagi sampai makan malam selalu dinikmati dengan cabenya yang segar. Kisah itu menggambarkan bahwa masyarakat palembang sangat menerima orang luar di lingkungannnya.

Namun, selain sebagai sebutan kota pempek, Kota Palembang juga dikenal sebagai kota pendatang khususnya dari etnis Tionghoa. Untuk mengetahui hal tersebut, masalah yang dibahas dalam penelitian ini adalah bagaimana bentuk adaptasi berbasis budaya dan masyarakat pendatang etnis Tionghoa terhadap lingkungan yang meliputi cara bertahan hidup dan perkembangan budaya, bisnis dan keturunannya berdasarkan pengamatan lingkungan, sosial, dan religi. Masyarakat Tionghoa di Kota Palembang seperti orang-orang Tionghoa yang ada di daerah-daerah lain di Indonesia, pada umumnya melaksanakan ritual-ritual yang berkaitan dengan pemujaan Budha dan Kong Fu Chu. Hal ini diperkuat dengan dukungan yang diberikan oleh Abdurrachman Wahid sebagai Presiden Indonesia ke 4 (19992001) yang memberikan kebebasan bagi warga Tionghoa untuk mengekspresikan diri dan mengesahkan Kong $\mathrm{Hu} \mathrm{Cu}$ sebagai aliran kepercayaan yang dianut oleh etnis Tionghoa menjadi agama yang diakui di Indonesia. 
Etnis Tionghoa hidup rukun dan toleran. Kebijakan yang diterapkan sejak tahun 2001 menunjukkan dan memberi pesan kepada masyarakat luas bahwa daerah itu dihuni warga berbagai suku dan agama, yang semuanya memiliki posisi setara. Berdasarkan permasalahan tersebut penelitian ini bertujuan untuk mengungkapkan bentuk adaptasi masyarakat pendatang etnis Tionghoa terhadap lingkungan, yaitu cara mereka beradaptasi dan perkembangan budayanya.

\section{METODE PENELITIAN}

Jenis penelitian ini adalah pennelitian kualitatif dengan menggali informasi dan data sedalam dalamnya dari informan. Metode pendekatan yang dilakukan dalam penelitian adalah metode pendekatan fenomenologis yaitu fenomenologis tentang kehidupan masyarakat Tionghoa dengan masyarakat pribumi baik dari budaya, adaptasi dan sosial-ekonomi nya.

Selanjutnya membuat deskripsi secara sistematis, faktual, dan akurat tentang fakta-fakta dari subjek dan objek yang diteliti. Prosedur kerja yang dilakukan peneliti adalah mengidentifikasi adaptasi berbasis budaya oleh etnis Tionghoa dengan masyarakat lokal.

Dalam mengumpulkan data untuk memperoleh informasi yang akurat peneliti mengambil data dari primer melalui wawancara langsung dengan informan penelitian yaitu masyarakat etnis Tionghoa dan pribumi dan didukung dengan data-data sekunder seperti data Badan Pusat Statitistik Kota Palembang, Kementerian Agama sebagai wadah umat beragama, Forum Komunikasi Umat beragama (FKUB) karena di forum ini di wadahi oleh pengurus yang berbeda agama dan tokoh adat dan tokoh masyarakat yang dianggap mampu memberikan data yang dibutuhkan peneliti.

Selanjutnya dilakukan observasi (pengamatan) terhadap aktvitas masyarakat etnis Tionghoa seperti kegiatan bisnis, kegiatan ritual dan kegiatan sosial keagamaan dan pemerintahan, pendidikan dan kesehatan. Terakhir, peneliti melakukan analisis data dari hasil transkip wawancara dengan informan dengan dengan langkahlangkah yang dikemukakan oleh Miles dan Hubermen yaitu reduksi data memilah data, membuat tema-tema, mengkatagorikan, memfokuskan data sesuai bidangnya, membuang, menyusun Setelah direduksi maka data yang sesuai dengan tujuan penelitian disajikan dalam bentuk kalimat sehingga diperoleh gambaran yang utuh tentang masalah penelitian dan menarik kesimpulan.

\section{HASIL DAN PEMBAHASAN}

\section{Adaptasi Budaya}

Kunci adaptasi adalah adaptasi yang memungkinkan individu untuk memahami individu lain sebagai agen yang disengaja seperti diri. Bentuk unik dari kognisi sosial ini muncul pada ontogeni manusia pada usia sekitar satu tahun ketika bayi mulai terlibat dengan orang lain dalam berbagai jenis aktivitas atensi bersama yang melibatkan tatapan mata, rujukan sosial, dan komunikasi gestural.

Budaya merupakan proses keseluruhan yang termasuk pengetahuan, 
kepercayaan, seni, moral, hukum, adat istiadat, dan apa saja kemampuan serta kebiasaan lain yang diperoleh manusia sebagai anggota masyarakat (Holden, 2002). Sehigga budaya dapat dilihat sebagai produk perilaku.

Definisi budaya yang terkenal lainnya adalah Kroeber dan Kluckholn (1952), yang juga mengaitkannya Gagasan budaya untuk perilaku. Mereka mengidentifikasi budaya sebagai pola gagasan dan nilai yang membentuk perilaku seseorang [11]. Dalam waktu yang lebih baru, budaya telah digambarkan sebagai "pemrograman kolektif pikiran yang membedakan anggota satu manusia grup dari yang lain "[12]. Hofstede menyarankan itu budaya tidak diwariskan tetapi dipelajari, karena diturunkan dari "lingkungan sosial seseorang" [12]. Budaya adalah "the cara hidup masyarakat" [13].

Budaya datang dalam berbagai bentuk seperti budaya fungsional, budaya organisasi, dan budaya nasional [5]. Sepanjang penelitian ini, istilah itu budaya digunakan untuk mewakili budaya nasional. Karya Hofstede dari tahun 1970 mengeksplorasi gagasan tersebut budaya nasional.

Demikian halnya kondisi adaptasi budaya masyarakat Tionghoa di Kota Palembang. Jika ditelisik kebelakang dari hasil temuan penelitian ini menggambarkan bahwa Penduduk Palembang merupakan etnis Melayu dan menggunakan Bahasa Melayu yang telah disesuaikan dengan dialek setempat yang kini dikenal sebagai Bahasa Palembang yang akhir kata selalu dengan huruf ' $\mathrm{O}$ ' Namun para pendatang seringkali menggunakan bahasa daerahnya sebagai bahasa sehari-hari, seperti bahasa
Komering, Rawas, Musi, Pasemah, dan Semendo. Pendatang dari luar Sumatra Selatan kadang-kadang juga menggunakan bahasa daerahnya sebagai bahasa sehari-hari dalam keluarga atau komunitas kedaerahan. Namun untuk berkomunikasi dengan warga Palembang lain, penduduk umumnya menggunakan bahasa Palembang sebagai bahasa pengantar sehari-hari.

Selain penduduk asli, didapati juga penduduk pendatang dari berbagai suku dan daerah seperti suku Jawa, Minangkabau, Madura, Bugis dan Banjar. Namun jumlah suku dan keturunan yang banyak Tionghoa sangat banyak.

Etnis Tionghoa melakukan interaksi dengan masyarakat Palembang menggunakan bahasa daerah baik dalam melakukan transaksi bisnis maupun lainnya. Penyesuaian iklim budaya oleh etnis Tionghoa dengan masyarakat lokal dapat dilihat dari aktivitas ekonomi dan kehidupan mereka sehari-hari seperti dalam transaksi bisnis/dagang.

Disamping itu juga Etnis Tionghoa di palembang banyak yang memeluk agama Islam sebagai keyakinannya. Proses Islamisasi ini ada yang melalui perkawinan maupun kerjasama bisnis. Diantara penduduk pendatang etnis Tionghoa banyak yang memilih untuk mencari pendamping hidupnya dari penduduk Palembang. Tujuannya adalah untuk mendapatkan keturunan dan bisa menetap. Upaya tersebut dilakukan sebagai bentuk prinsip yang dibangun oleh masyarakat Tionghoa agar dapat membaur dengan masyarakat lokal dan mendapatkan keamanan dan kenyamanan. 
Adaptasi Sosial Dan Politik

Etnis Tionghoa di seluruh Indonesia menbuat organisasi khusus etnis Tionghoa yang disebut dengan "Persatuan Islam Tionghoa Indonesia (PITI). Menurut Tulisan Herwansyah PITI berdiri dijakarta tanggal 14 April 1961 yang di prakarsai oleh Goan Tjin.Terbentuknya PITI adalah merupakan gabungan dari persatoen Islam Tionghoa yang berbasis di Medan dan persatuan moeslim Tionghoa yang berbasis di Bengkulu.

PIT dan PMT sudah muncul pada tahun 1930 di prakarsai oleh H. Abdul Karim Oei Tjeng, dan H. Abdussomad Yap Asiong. Persatuan ini pada awalnya di peruntukkan untuk orang yang baru pindah agama ke Islam akan tetapi seiring dengan perkembangan zaman semua muslim Tionghoa bergabung dalam naungan organisasi ini.

Peran Arya Damar yang merupakan ayah angkat dari Raden Fatah yang diganti nama menjadi Parlindungan adalah seorang etnis Tionghoa. Nama asli beliau adalah Swan Liong sangat besar perannya dalam mengembangkan islam di Palembang. Beliau merupakan utusan pemimpin komuniats china di Asia tenggara. Raden patah dalam sejarah disebut bernama Djin Bun yang merupakan anak dari raja sriwijaya yang lahir dari ibu keterunan China (Skinner, 1963).

Ahli sosiologi menyebutkan bahwa keturunan palembang itu adalah keturunaan etnis Tionghoa karena kemiripan warna kulit dan wajah pada masyarakat palembang., beberapa menyebutkan sebagai keturunan China. Komunitas Tionghoa. Muslim Tionghoa
Palembang secara budaya dan agama sudah melebur dengan baik ini dilihat dari bahasa yang di gunakan dan makanan yang dikomsumsi sebagai ciri khas palembang (Suryadinata, 2001). Di sisi lain etnis Tionghoa juga aktif di bidang politik. Pemilihan umum dengan sistem demokrasi saat ini memberi peluang kepada semua warga negara yang memenuhi persyaratan untuk duduk di legislatif.

Pada jaman orde baru warga Tionghoa lebih banyak berkiprah di dunia bisnis. Seperti yang diutarakan pada latarbelakang masalah sejak kepemimpinan Abdurrahman Wahid warga china mendapat angin segar dan memilki kebebsan di negara Indonesia.Sejak saat itu banyak masyarakat Tionghoa yang terjun kedunia politik. Di wilayah Palembang khususnya Batu Raja ada beberapa orang warga Tionghoa yang ikut menjdi calon legislatif dari partai nasionalis dan salah satu diantaranya memperoleh suara pada kursi DPRD periode 2019-2024.

Dalam menentukan pilihan masyarakat Palembang masih mempertimbangkan asal ususl calon legislatif terutama dalam pertimbangan agama. Etnis Tionghoa banyak aktif di berbagai partai politik. Baik muslim Tionghoa maupun Tionghoa non muslim. Kemampuan ekonomi tidak menjadi ukuran untuk mendapatkan kursi. Seorang calon anggota DPR harus memiliki banyak pendukung terutama dukungan dari penduduk lokal. Faktor kedaerahan menjadi dominan dalam menentukan pilihan rakyat. Tidak terlepas juga faktor kayakinan (agama) juga tidak boleh diababaikan begitu saja. 
karena hal ini juga menjadi pertimbangan bagi.

\section{Adaptasi Sosial Masyarakat}

Di Palembang ditemukan identitas Muslim-Tionghoa terbagi menjadi dua: Pertama, Tionghoa peranakan yaitu keturunan Muslim dari Tiongkok sejak abad 17-18 dan bukan dari hasil politik segregasi masa Kolonial, melainkan seiring upaya mereka mempertahankan identitas masa lalunya yang telah memiliki prestise sendiri dalam masyarakat Islam tradisional Palembang. Kedua, Tionghoa Muslim konversi yaitu kelompok Tionghoa non Islam yang konversi ke agama lain. Kelompok ini diwakili oleh PITI (Persatuan Islam Tionghoa Indonesia) Palembang. Kedua kelompok tersebut memiliki kontribusi yang cukup besar dalam pembinaan umat Islam di Palembang (Hermansyah, 2017).

Dapat disimpulkan bahwa adaptasi sosial yang terjalin antara etnis Tionghoa dan masyarakat Palembang telah terjalin melalui jalur perdagangan atau bisnis dikarenakan Palembang merupakan Bandar terpenting bagi perdagangan dan pelayaran Indonesia bagian Barat yang menghubungkan dua kawasan pedagang Asia, yakni Cina, India dan Arab. Bahkan Palembang merupakan salah satu Bandar terpenting bagi terbentuknya komunitas yang berciri kosmopolitan, yakni periode kerajaan maritim Sriwijaya maupun pada masa kesultanan Palembang (Hanafiah, 1990).

Sampai saat ini, etnis Tionghoa di Palembang telah berbaur dengan masyarakat. Maka tidak heran jika melihat orang-orang Palembang diidentik dengan mata sipit dan kulit putih. Dengan membaurnya masyarakat etnis Tionghoa dengan masyarakat pribumi Palembang, banyak terjadi pertukaran budaya, dan tidak dipungkiri terjadi perkawinan diantara mereka.

Adaptasi ini masih berlangsung sampai saat ini. Maka dari itu, tentunya Etnis Tionghoa memiliki budaya dan ciri khas yang berbeda dengan masyarakat Palembang. Seseorang yang memilih strategi adaptif cenderung memiliki kesadaran yang tinggi terhadap harapan dan tuntutan dari lingkungannya, sehingga siap untuk mengubah prilaku. Dalam melakukan adaptasi tentu akan menemukan tantangan-tantangan baru yang bahkan belum pernah dialami. Jika mampu melewati tantangan itu, maka akan memudahkan golongan masyarakat dalam melakukan interaksi sosial meski dengan beberapa perbedaan yang ada.

Proses adaptasi etnis Tionghoa di Palembang, dilakukan melalui dua tahapan seperti yang dikemukakan oleh Kim. Tahap pertama, Cultural adaptation merupakan proses dasar komunikasi yang mana ada penyampai pesan, medium dan penerima pesan, sehingga terjadi proses endcoding dan decoding. Proses ini diidentifikasikan sebagai tingkat perubahan yang terjadi ketiak individu pindah ke lingkungan yang baru. Terjadi proses pengiriman lokal (Palembang) di lingkungan baru tersebut yang dapat dipahami oleh individu pendatang (Tionghoa), hal ini dinamakan enculturation. 
Gambar 1: Hubungan antara istilah kunci dalam adaptasi Budaya (Kim, 2001).

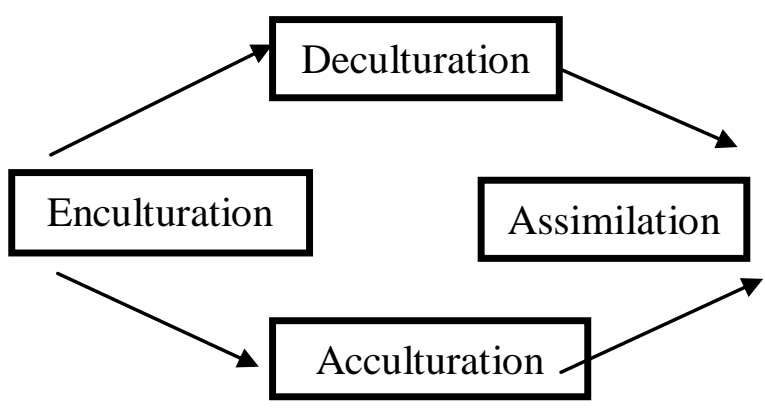

Keterlibatan etnis Tionghoa dalam pemerintahan di masa silam tidak bisa dihilangkan dalam sejarah. Salah satunya sebutan Kapitan ialah panggilan buat para Kapten Tionghoa dalam memimpin etnis maupun pemerintahan. Dari pemaparan ini dapat diketahui bahwa kelompok generasi kedua MuslimTionghoa masih ada hingga sekarang. Meski jumlahnya sedikit namun pada masa Kesultanan Palembang Darussalam mereka diberikan kedudukan yang istimewa karena status agamanya. Hal ini menjadi bukti bahwa etnis Tionghoa benar-benar berasimilasi baik secara structural (diangkat sebagai pejabat) maupun kultural diwujudkan dengan peran mereka dalam mengembangkan ajaran Islam, namun identitas Tionghoa masih dipertahankan. Seperti halnya panggilan Koko dan Cici terhadap lelaki dan perempuan bujang.

Temuan terakhir dalam penelitian ini bahwa Etnis Tionghoa tetap mempertahankan identitasnya meski telah berintegrasi secara total dengan masyarakat lokal terutama MelayuPalembang. Perlu untuk digaris bawahi bahwa agama memiliki ikatan kuat dalam rangka mengintegrasikan antara keturunan Tionghoa dengan Pihak
Kesultanan Palembang Darussalam. Selain itu dapat dilihat dari tokoh Ulama besar di Palembang KH Amin Azhari yang menjadi rujukan dalam menentukan hukum Islam, ia tetap mempertahankan identitas Ketionghoan-nya.

Orang-orang Tionghoa yang lahir non Islam. Mereka yang non Islam ini kemudian konversi menjadi Islam. para muallaf Tionghoa itu kemudian mendirikan organisasi PITI, hingga saat ini PITI masih berperan sebagai wadah bagi orang-orang Tionghoa yang telah konversi ke dalam agama Islam.

Jika dilihat lembaran sejarah di masa pemerintahan Suharto, PITI dijadikan instrument Negara dalam melakukan fungsi asimilasi komunitas Tionghoa terhadap pribumi. Keberadaan PITI didukung oleh pemerintah, hal ini terlihat dengan adanya struktur organisasi yang memiliki birokrasi dari tingkat pusat dan menyebar ke beberapa daerah, salah satunya Palembang.

\section{SIMPULAN}

Adaptasi budaya dan masyarakat etnis Tionghoa sebagai pendatang di Kota Palembang merupakan bagian dari proses pembangunan. Etnis Tionghoa sudah mampu melakukan adaptasi budaya dan sosial masyarakat dengan baik di Kota Palembang. Kemampuan tersebut terlihat dari kehidupan sosial ekonomi, kemasyarakatan dan budaya etnis Tionghoa yang mampu bertahan hidup dengan modal pengembangan usaha dagang dan berkecimpung di bidang politis. Selain itu, etnis Tionghoa juga mampu beradaptasi secara struktural dan kultural dengan mengikuti 
perkembangan budaya dan masyarakat

Kota Palembang.

DAFTAR PUSTAKA

Ardianto, E. (2010). Metodologi Penelitian Public Relation Kuantitaf dan Kualitatif . Jakarta: Simbiosa Rekatama Media.

BPS. (, 2018). Kota Palembang Dalam Angka 2018. Palembang: Badan Pusat Statistik.

Hanafiah, D. (1990). Sejarah Perkembangan Pemerintah Kotamadya Daerah Tingkat II Palembang. Palembang: Pemda Tk II Palembang.

Hermansyah. (2017). Tipologi Identitas Muslim Tionghoa di Palembang Sumatera Selatan. Journal JIA UIN Raden Fatah Palembang, 19.

Holden. (2002). Cross-Cultural Management: A Knowledge Management Perspective. UK: Prentice-Hall.

Kim, Y. Y. (2001). Becoming Intercultural: An Integrative Communication Theory and Cross-Cultural Adaptation. USA: Sage Publication.

Purba, J. dkk. (2012). Kota Bontang Dinamika, Sejarah, dan Perkembangannya. Bontang: Dinas Kebudayaan dan Pariwisata Kota Bontang.

Rakhmad, J. (1984). Metode Penelitian Komunikasi . Bandung: Remaja Rosdakarya.

Skinner. (1963). "The Chinese Minority" Indonesia. New Haven: HRAF.

Stavenhagen R. (1998). 'Cultural rights: a social science perspective', in Niec, $\mathrm{H}$. (ed.) Cultural Rights and Wrongs. Paris: UNESCO

Suharyanto, A. \& Hidayat, T.W. (2017). Revealing Medan's Chinese Ethnic Identity in Advertising Grief at Harian Analisa Newspaper. Budapest International Research and Critics Institute (BIRCIJournal ...

Suharyanto, A. Matondang, A. (2017). Makna Upacara Cheng Beng pada Masyarakat Etnis Tionghoa di Medan. Prosiding Seminar Nasional Pakar, 21-26

Suharyanto, A. Matondang, A. Walhidayat, T. (2017). The Interpersonal Communication of the Chinese Ethnic Families in Cheng Beng Ceremony in Medan, Indonesia. IOSR Journal of Humanities And Social Science (IOSR-JHSS), 22(12) Ver.4:38-44.

Suryadinata, L. (2001). Kebudayaan Minoritas Tionghoa di Indonesia. Jakarta: Gramedia.

Sutton, M. and A. (2010). Introduction to Cultural Ecology (2nd ed.). Lanham: Altmira Press. 